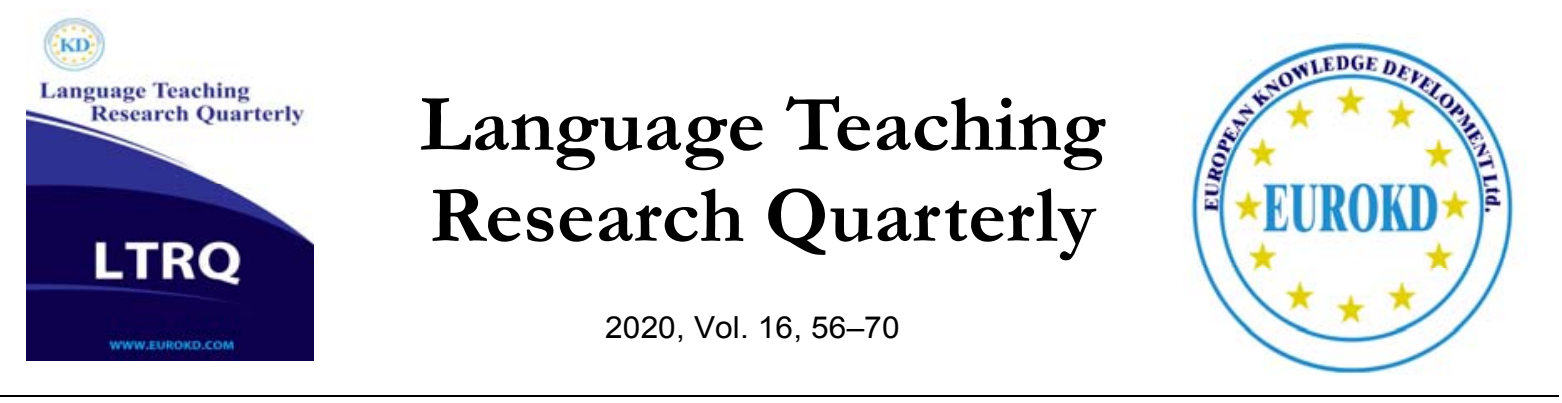

\title{
The Reasons of Using L1 in ESL Classrooms
}

\author{
Huda Murad Abdul Rahman Al Balushi \\ International Maritime College, Oman
}

Received 19 June 2019 Accepted 09 April 2020

\begin{abstract}
This study investigates the reasons for L1 use in the L2 classroom and teachers' and learners' beliefs regarding the appropriateness and effectiveness of this practice. Its findings are based on observational and interview data collected in two lower intermediate level classes in the foundation year at an Omani university. Each class was observed three times over a two-week period, with each session lasting 1 hour 40 minutes. The interview data were obtained from the teacher and three students from each class. One of the classes was designated as an experimental group, in which the teacher was permitted to use L1, whereas the second class was used as a controlled group where an 'English only' policy was strictly adhered to. The results show that L1 was used most often to explain word meanings, followed by explanations of grammatical rules. Instances of L1 use were also recorded during L2 to L1 translation exercises, and L1 was used for classroom management purposes and for telling jokes.
\end{abstract}

Keywords: Teacher's beliefs, $L 1$

\section{Introduction}

This study has been conducted to investigate why ESL teachers use the L1 in the L2 classroom. Since I share the mother tongue with my students, it allows me to use the L1 with them when it is needed. However, when I was appointed for the position of an English language teacher at one of the colleges in Oman, I was suddenly confronted with a much less flexible attitude to L1 use in the classroom. Before starting teaching, all the teachers were given a workshop about the college's rules, and one of them was "L1 use is taboo"! That was a shocking idea as I was a fresh graduate who was not yet fluent in English. We were not supposed to use Arabic at all in the classes. Since then, I have withdrawn from that college because I feared that I would not be able 
to continue teaching there. After one year, I was hired by another college to teach English. However, this institution was also a supporter of the 'English only' policy in communicative language teaching. I accepted this and made a commitment to start the journey of teaching English without using L1. Unfortunately, I was shocked by the low proficiency level of the students who had just joined the college and were placed at level 1 and 2, which are the lowest levels in the college and equivalent to CEFR level A. Each class had an average of 24 students, both male and female, aged between 18 and 25. I taught them using communicative language teaching, and applied the 'English only' policy but I soon found that this approach was not working because some of the students were not able to understand even slow easy speech. This led me to use L1 in some cases, especially when some students were struggling to understand the grammatical points introduced in class. I sat with them and explained the rules in L1 (Arabic), and I noticed that this made a positive impact on their progress. This experience prompted me to investigate the use of L1 using scientific methods and explore why the 'English only' policy is so common in Omani higher education institutions and how it is viewed by local teachers and learners.

\section{Literature Review \\ Communicative language}

Communicative language teaching has been widely used and recommended in most of Omani higher education intuitions, including the place where I work, because of its great effects. It is believed that "Language learning is seen as essentially a long process of acquisition through exposure to and communicative use of the language" (Davies and Pearse, 2000: 194). Communicative teaching requires subconscious acquisition and conscious learning and it develops learners' autonomy. One can deduce that communicative teaching is affected by the natural approach, which was developed by Tracy Terrell in the late 1970s in collaboration with Stephen Krashen. Davies and Pearse (2000) provide more explanation of the natural approach in which the language is acquired through hearing and then using it in communicative activities. Increasing comprehensible input facilitates language acquisition, which is a largely subconscious process, while formal study, which is based on conscious learning, is considered a waste of time since it is believed to play a minor role in learning. Along with this, Krashen and Terrell (1983) believed that "adult language students have two distinct ways of developing skills and knowledge in a second language. Simply, acquiring a language is "picking it up," i.e., developing ability in a language by "using it in natural, communicative situations" (p. 18). Though the natural approach focuses only on subconscious acquisition, communicative teaching adds a conscious element to the learning process that helps the learners notice the language.

Auerbach (1993) argues that:

English only movement on a policy level insist that their students use English as the sole medium of communication; teachers devise elaborate games, signals, and penalty systems to ensure that students do not use their L1 will impede progress in the acquisition of English ( $\mathrm{p}$. $10)$. 
Although using the communicative language teaching approach and applying the English only policy is beneficial in learning a language, it might not suit all levels and all students as L1 is ignored in these situations. This study, therefore, seeks to shed light on the reasons for L1 use in the L2 classrooms, whether by teachers or students. With this objective in mind, the study investigates the following three research questions:

RQ1. What are the purposes of using L1 in English language classrooms?

$\mathrm{RQ}_{2}$. What are the ESL teachers' beliefs about L1 use?

RQ3. What are ESL students' beliefs about L1 use?

\section{Teachers' Cognition and Beliefs}

The ultimate goal of learning and teaching is learning a language by learners, and according to Woods (1996), what the language is, how it is learned, and how it is taught depends on teachers' beliefs, assumptions and knowledge (hereafter, BAK). The assumptions about learning "affect the way we assume we should teach the material; and the assumptions about language determine what the material is. We can teach explicitly, implicitly, in relative isolation or relative contextualization" (ibid. p. 189). There are many assumptions about teachers' and students' roles, classroom organization and disciplines. Teachers use the knowledge and information they have to guide their teaching, but when the required knowledge is not available, they rely on their beliefs.

Before we start talking about beliefs, it is important to define this term. Belief has been defined in various ways, Borg (2001) suggests that belief is "a proposition which may be consciously or unconsciously held, is evaluative in that it is accepted as true by the individual, and is therefore imbued with emotive commitment; further, it serves as a guide to thought and behaviour" (p. 186). Thus, teachers' beliefs are to some extent responsible for their practices in the classrooms and determine whether L1 is used in the L2 classroom by the teacher. As beliefs are one of the key factors affecting L1 use, much research has been conducted to investigate teachers' beliefs.

Among such studies is Al Alawi (2008), which investigated the effect of teachers' beliefs regarding L1 use on their behaviour, using interview and observational data from five English language teachers working with grades 5-9. Based on lessons observations, Al Alawi finds that L1 is used most often while giving instructions, whereas it is least common in classroom management. The interview data, however, show that the practice varies between teachers. Some teachers strongly opposed the idea of using L1 as in their opinion it hindered L2 learning; others encouraged the idea of using L1 'wisely', that is, in a way that did not allow the learners to become over-reliant on L1. Yet others held the belief that permitting L1 use saves time, especially when translating difficult words, and it creates a relaxing environment for students. According to those participants, L1 allows the teachers and students to, for example, use humour in class, which can strengthen the relationship between the teachers and the learners.

Regarding the belief about grammar teaching, Borg (2006) has summarized the results of many studies done by different researchers. For example, Chandler (1988) finds that the source 
of grammatical knowledge is based on teachers' prior experiences at schools. Another study conducted by Eisentein-Ebsworth and Schweers (1997) built on the previous study and concluded that teachers' views are shaped by their experience as teachers and learners, as well as by students' needs and curriculum expectations. Moreover, Schulz $(1996,2001)$ finds that there is a mismatch between teachers' views and learners' expectations of error correction. He finds that despite teachers' assumptions to the contrary, $94 \%$ of students welcome being corrected by teachers. He further argues that about $80 \%$ of students are in favour of formal grammar teaching, even though $36 \%$ of teachers thought that students were opposed to this practice. Indeed, Borg (2006) argues that this mismatch between the views of teachers and learners may have a negative impact on students' motivation.

Rivers and McMillan (2011) add that teachers' beliefs are affected by many factors, such as "their own experiences as L2 learners, teacher training, teaching experiences, official policies, and through exposure to the perspectives of colleagues and supervisors" (p. 253). Phipps and Borg (2009) suggest that two types of beliefs can be found in their data. These are, core beliefs, which are more stable and have greater influence on teachers' behaviour, and peripheral beliefs, which are less powerful and effective. They highlight the tension between teachers' beliefs and practices in the classroom. They conclude that although teachers may believe something, there are many factors that affect and shape their behaviour in the classroom, including time constraint, curriculum demands, students' own expectations about teacher behaviour in the classroom, and classroom management techniques. For example, many teachers believe in group work but for classroom management and monitoring reasons, they may choose to avoid it.

Some believe that using L1 in L2 classes hinders L2 learning and it is believed that adult L2 learning should proceed in the same manner as L1 acquisition in children (Mitchell, 1988 cited in Chambers, 1991). Ellis (1984) also emphasizes the importance of using the L2 even in classroom management and organizing tasks, as he believes that if teachers use L1 "they deprive the learners of valuable input in the L2" (p. 133). That is the comprehensible input which is modified to suit students' level with emphasis on repetition and contextualization. Bolitho (1976) further argues that "If the mother tongue is used too frequently, the pupils may soon lose the will to make the effort to concentrate solely on communicating in the target language" (p. 112).

Duff and Polio (1990) have measured the amount of L1 used in the classes they observed. They find that more than half of the teachers that they have observed use L2 less than $90 \%$ of the time, whereas the rest use L2 to the maximum. These teachers believe that to maximize the use of L2 in class, they could adopt a series of strategies. Some advocate employing verbal modification, including the use of simple words and repetition, to make the language more accessible for students. While others recommend using nonverbal means like gesture and visuals. Another strategy is to officially introduce an 'English only' policy at the beginning to help students to get used to using the target language. Although some of the teachers used L1 while teaching grammar, it is very important to state the grammatical terms at the beginning, and if L1 is needed, it is better to provide students with supplementary materials in L1 for use outside the 
classroom, or to allocate the last 5 minutes of each grammar class to answering students' questions in L1 (p. 162-3).

\section{Methodology}

Observation is one of the methods used for data collection. While conducting observations, the researcher can be a part of the observed group and interact with them, and this type of observation is called 'participant observation'. Conversely, the second type of observation is called 'unobtrusive observation' when the researcher watches the participants and records their behaviour (Driscoll, 2011). In my study, I have used the second type of observation. Before the observations began, a verbal consent was obtained from all participants and every effort was made to ensure confidentiality and anonymity throughout the process. In line with the purpose of the observation, only the teacher whom I observed knew the aim of my study. This information was withheld from the students to ensure that their code-switching behaviour in class would not be changed for the benefit of the research. At the beginning, I planned to record the observations, unfortunately this was not allowed by the college. Instead, the data were collected using detailed field notes.

In addition to observation, I used interviews to collect further data. First, the interview was piloted by using email. Due to time constrains and the distance, the questions were sent to one of the voluntary teachers who agreed to do the interview via email. Although the teacher answers all the questions, most of the answers were short and did not go into detail. Some of the answers were the opposite of what was needed (this can be seen in Appendix III). This led me to abandon email interviews and use face to face interviews instead. This form of data collection was better suited to explaining any potential misunderstandings and ensuring more in-depth responses from the interviewees.

The interviews I conducted were structured in that they used standardized questions so all the interviewees were asked the same questions in the same order (Borg, 2006). This allowed me to focus on specific areas. The questions included closed questions that required limited answers and more open-ended questions to give the interviewees a chance to respond freely. The openended questions were used most of the time to get a better idea about the participants' cognition and beliefs, as suggested by Borg (2006). Moreover; Cohen and Manion (1994) claim that openended questions are more flexible, they reduce the chance of misunderstanding, encourage cooperation, build a good rapport, and make reliable assessment of what interviewees believe (p. 277). The question format also varied. Tuckman (1972) listed four types of questions: direct or indirect, general or specific, factual or opinion, question or statement. Most of the questions were direct and ranged from general to more specific towards the end of the interview. All the interviews were face to face, which is friendlier and we can understand the body language which sometimes conveys indirect messages from both the interviewee and the interviewer. All the interviews were recorded using the phone application "Voice Memo".

On the other hand, focused and unfocused interviews are more flexible and although they help explore the interviewee's opinions in greater detail, not all the interviewees are asked the same 
questions, making it "more difficult to interpret differences obtained when responses are compared" (Dane, 1990, p. 129). Interviewees may also talk about irrelevant topics, which is not helpful. Although, Cohen and Manion (1994) argue that interview may lead to subjectivity on the interviewer's side, it has the advantage of providing information of 'greater depth'.

\section{Data Collection}

The data was collected at the Technical College at Shinas in Oman. My focus was on English classes, therefore I chose to collect data from foundation year students, especially those at the lowest proficiency levels. As the data collection was undertaken in summer, I observed classes at the summer school semester. Two classes of the same level (level 2, equivalent to CEFR level A), who were taught by the same teacher, were observed over two weeks. Each group was observed on three occasions after obtaining permission from the dean of the college, the head of the foundation studies department, the teacher I observed and the students in each class. A letter was sent to the dean (see appendix II) and the head of department (see appendix I), and verbal permission was taken from the teacher and the students. The participants were told that all obtained data would be processed securely and all personally identifiable information would be anonymised. Both groups consisted of 22 students, aged between 18 and 20. All students are Omani, whose L1 is Arabic. The two classes were divided into a controlled group in which L1 was not allowed at all, and an experimental group where L1 was permitted. An Omani teacher was suggested by the Head of Foundation Department as I wanted a non-native speaker of English who knows students' L1. After the observations were completed, six students were interviewed, three students from each group, and the teacher was interviewed as well.

\section{Participants}

The six students are all Omani from different regions of the country, and all of them studied English from grade 1 (age 7); thus, at the time of the data collection they had been studying English for twelve years. Two male students were chosen from each group and only one female student was chosen from each class as most of the female students were shyand did not want to participate. All the interviews with the students were conducted in Arabic since this was their preferred option. I agree with Hayes (2009) that when doing interviews, the participants would speak in English but sometimes they would use Thai "where they felt it necessary to convey a concept or a particular piece of information for which they could not think of the English equivalent" (p. 3).

Moreover, the teacher was a female Omani teacher whose L1 is Arabic. At the time of the data collection she had been teaching for two years and she had completed a Master's degree at the University of York in the United Kingdom. The interview was done in English, as both of us are fluent English speakers. The interview questions were very similar to the students' questions because I wanted to compare the answers between the teacher and the learners. All the interviews lasted 10 to 15 minutes. 


\section{Procedure}

The first method of data collection used in this study was observation. The students and the teacher were observed first to get some information about the teacher, the students, teaching strategies, L1 usage and teachers and students attitudes regarding this practice. In addition, observing the classes helped me in choosing students for the interview, and I chose them based on their talk, behaviour and reactions in the classroom. The observations were followed with interviews. During the observations, a checklist was used containing the reasons for L1 use in the classroom based on my review of the relevant literature. I had listed seven common reasons for L1 use: managing the classroom, giving instructions, telling jokes in L1, comparing and contrasting between L1 and L2, explaining abstract words, translating sentences, and explaining grammar. During the interview, I only took notes as recording and videotaping was not permitted by the college.

I observed the two classes a total of six times with each session lasting 1 hour 40 minutes, and each class was observed three times. Although observation is time consuming, as Blaxter, Hughes and Tight (2010) argue, Wilkinson and Birmingham (2003, p. 117) believe that "it can allow researchers to understand much more about what goes on in complex real-world situations than they can ever discover simply by asking questions of those who experience them". Observation helped in noticing many areas, which I did not pay attention to before. However, according to the teacher, during the first observation, my presence affected the students' participation in class. The students were quieter and not willing to participate. But by the time of the second and third observation, the students got used to my presence in the classroom. They understood that I was simply an observer, who was taking notes at the back of the class and watching the students' and teacher's behaviour.

Using these tools helped me answer the first research question, namely: What are the reasons for L1 use in L2 classrooms?

Table 1.

Research Methodology

\begin{tabular}{|c|c|c|}
\hline Specific research questions & Data collection instruments & Data Analysis \\
\hline $\begin{array}{l}\mathrm{RQ}_{1} \text {. What are the purposes of using L1 in English } \\
\text { language classrooms? } \\
\text { RQ2. What are the ESL teachers' beliefs about L1 } \\
\text { use? } \\
\text { RQ }\end{array}$ & $\begin{array}{l}\text { Classroom observation } \\
\text { Interviews ( } 1 \text { teacher and } 6 \text { students) }\end{array}$ & Content analysis \\
\hline
\end{tabular}

\section{Data Analysis}

Data has been analyzed using the content analysis method. Dane (1990) suggests that content analysis is "a research method used to make objective and systematic inferences about theoretically relevant messages" (p. 170) and it is used for "analyzing written, verbal or visual communication messages" (Cole 1988 in Elo and Kyngas, 2008, p. 107). This method is used to analyze the messages which are heard during the interviews and it makes inferences about events 
and relates them to theory. Dane (1990) believes that inferences must be objective, which means the inferences should be similar to others' inferences in the same field. Krippendorff (2004) agrees with this statement and refers to it as 'replicability'.

"Content analysis provides new insights, increases a researcher's understanding of particular phenomena, or informs practical actions" (Krippendorff, 2004, p. 18).

\section{Findings}

\section{Classroom Observation}

Based on the observations, the teacher used L1 in some situations which were noted using the checklist described earlier. Even though I observed two groups - a controlled and an experimental group - the teacher used Arabic in both of them, as she claimed that the students' level did not allow her to use English only and the topic of the class was particularly difficult and could not be taught without recourse to L1. The results are summarized in Table 2 below.

Table 2

Class Observation Results

\begin{tabular}{lc}
\hline Reasons for using L1 & Numbers of occurrence \\
\hline Managing the classroom & 1 \\
\hline Comparing and contrasting between L1 and L2 & 0 \\
\hline Explaining abstract words & 7 \\
\hline Translating sentences & 1 \\
\hline Explaining grammar & 5 \\
\hline Telling jokes & 1 \\
\hline
\end{tabular}

\section{Classroom management}

One of the students was annoying the class and the teacher got angry with him and asked him to stop talking in Arabic. Then she warned him in Arabic that she would send him out of the class.

\section{Word meaning}

The teacher wrote "I have washed the dishes", and the students asked her about the meaning of "dishes". She said "plate", but the students did not get the right meaning and said in Arabic "We don't know this word either". And then she said "It is something we eat from". Then the students said "Sahan", which is the equivalent word in Arabic and the teacher said "Yes, it is Sahan".

The teacher instructed the students to write sentences about their experience and she asked them "Do you know what it means?" one of the students replied "Khebra" in Arabic. The teacher praised the student and asked the rest of the class to repeat the meaning in Arabic.

Another word that came up during one of the tasks was "seasick". The students asked the teacher about the meaning of the word and she said "When you look at the sea you feel sick", and the students understood the meaning. On another occasion one of the examples contained the word "vase". The teacher explained in English that it was something we put flowers in. The students replied using the Arabic word for "vase" - "Mazhariya". 
When the teacher was explaining "specific and unspecific time", she repeated the meaning in Arabic because most of the students showed that they did not understand, and she said "MhaddadwaGhairMhaddad". Finally, the word "vacation" was used in one of the examples and one of the students gave the direct equivalent in Arabic, which is "Otlaa". However, the teacher insisted on finding a suitable synonym in English, and one of the students proposed the word "holiday".

\section{Sentence Translation}

While the teacher explained "She hasn't gone yet", she asked students questions like: "Where is she now? Is she gone?" but the students did not understand. She translated it into Arabic -“"Baadhamaarahat fi al soorabaaadhamawjooda", which means "She is still here because we can see her in the picture".

\section{Grammar Explanation}

The teacher draws a line on the board to show the use of present perfect to talk about something that happened in the past and continues to the present, and then she translates it into Arabic by saying "Hadathhasal fi al madhiwayastamer fi al hadher" and then she explains a situation in Arabic "shaisar fi al madhiwalahotatheer fi al hadhermathalananadakhalt al saafwa can wasekhwaasabtwarajaatwahasltonadheef" which means in English "Something happened in the past and has result in the present, for example if I come to the class and I find it dirty and get angry and went out, and after a while I came back and find the class clean"

Another situation when the teacher explains "finished and unfinished time", the students were not able to get the meaning and she gave them a direct translation: "MuntaheewaGhairmuntahee".

Explaining the use of "ever" was a bit difficult, so the teacher tried to explain the word 'ever' in English by saying "ever means the situation of doing something in your life, whether you do it or not and it is used in the questions" the students were still unable to understand the rule, so the teacher said "Fee hayatakabadn" which translates as "In your life ever".

To show the difference between "gone" and "been", the teacher used Arabic alone. The students were happy with the explanation in Arabic and commented "Now we understand".

\section{Telling Jokes}

The teacher told jokes to the students to break the ice and one of the jokes I noted was "Are you here or in Wadi Al Molook", which was used to get the attention of the class.

\section{Students Chatting}

Another thing that was noticed during the observations is student talk. One of the girls was annoyed by drawings on her table and she complained to her friend in Arabic, saying "Who did that?!" 
Most of the students were chatting with each other in Arabic during tasks. During their 10minute breaks, they were happy to use their phones and chat in Arabic; however, the teacher would try to encourage them to use English also during break time

\section{Interviews}

\section{Teacher interview}

The opinions expressed by the teacher and the students in the interviews were used to explain their actions in the classroom. I will begin by discussing my interview with the teacher and answer research questions 1 and 2 which relate to teacher's use of L1:

RQ1. What are the purposes of using L1 in English language classrooms?

RQ2. What are the ESL teachers' beliefs about L1 use?

The points related to L1 use made by the teacher in the interview are summarized below:

\section{Grammar Explanation}

The teacher uses L1 during grammar explanation, but she uses it as the last resort when she finds that students are struggling with the grammar points covered in class. She believes that as she shares the L1 with her students, she is better able to show the students the differences between

She also believes that students' proficiency level and the topic of the lesson also impact on her use of L1 in the classroom. And she gave the example of the present perfect tense as being particularly difficult to explain in English.

\section{Classroom Management}

Another context in which the use of L1 by the teacher is common is classroom management and discipline. She believes that stating the rules at the beginning of the semester helps a lot but sometimes the teacher needs to speak in L1 when she is forced to do so. However, she believes that "sometimes when you keep using Arabic, you will not be able to control the class. They will get used to it and they will want Arabic all the time."

\section{Jokes Telling}

The teacher believes that telling jokes in Arabic is very important to change the mood of the class and to build a good relationship with the students and she explains her use of humour in class as follows:

You know at the begging the asked me what is wadi al Molook, I said this is your homework go and look for it, where is wadi al Molook. Now, they know me when I say are you with me or in wadi al Molook, then they will focus with me because I know that they are not in the class, somewhere else. And you know they will keep laughing just as a way to change the mood.

Therefore, the teacher believes that L1 use in the L2 classroom is very important and she uses it as the last resort. She also argues that it is better to have a teacher who shares the same L1 with the students to be able to point out the differences between the two languages and at the same time know exactly what the students may find particularly hard to learn. From her point of view, 
her prior experience of being a student has shaped her way of thinking and her preference for an Arabic-speaking teacher. Moreover, when I asked her "How do you evaluate yourself when you speak in Arabic?" she replied:

You know I feel that way, but you know it depends on the class. Some students or some classes they like when I speak in Arabic or explain something in Arabic but some students you will have the feeling that what is this! Are we studying here Arabic or English? But of course not all the students. But for the weak students, I think they like the idea of using L1.

She emphasizes that the students' proficiency level is an important factor in deciding whether or not to use the L1.

\section{Students Interviews}

Six students have been interviewed and asked different questions related to research question 1:

RQ1. What are the purposes of using L1 in English language classrooms?

Regarding this question, students' answers illustrated many situations in which the teacher uses the L1. They have been summarized as follows:

- Grammar explanation 1

- $\quad$ Time saving

- Jokes telling

- Classroom management

Students A, B, C, E, and F agree on the main purpose of using L1 in relation to teachers, which is to explain grammar rules when students struggle to understand them. Student D, for example, believes that the teacher "Used Arabic because she didn't want to waste time" and she could use different techniques to facilitate comprehension instead of using L1. Further, student ' $A$ ' notes that the teacher tells jokes in Arabic, which is good for creating a comfortable atmosphere.

RQ3: What are ESL students' beliefs about L1 use in the L2 classrooms?

\section{Using L1 when not Understanding a Rule}

To be able to answer this question, students were asked different questions:

a. Do you use Arabic or English to ask the teacher to explain what you do not understand?

Here, I meant the grammar rule specifically.

Only one student, student E, believes that it is better to explain what the students do not understood in English first and then shift to Arabic. However, five of the students support the use of L1 when explaining new language. They state different reasons, for example, students A, C and $\mathrm{F}$ believe that it is easier to explain the rule in Arabic and it is easier to understand it. Student $\mathrm{B}$ further argues that

I will ask the teacher to explain in Arabic as it is the best way to understand the rule. I prefer the explanation to be in Arabic because sometimes you face difficult words which you don't know their meanings. So, I see Arabic is the easiest way to convey a message and explain a rule. 
While student D asks the teacher to provide an explanation in L1 to avoid being embarrassed in front of his friends.

\section{Their view of teachers who use L1 in the L2 classroom}

Although students' views vary, they generally agree with the teacher who uses L1 and all of them believe that the teacher knows when to use L1 and when not to. For instance, student A states that "The teachers don't use Arabic unless they find that the students are struggling and the teachers' role is to let the students understand, so they use it for a purpose which is helping students".

Student B says:

Honestly, I really admire the teachers who use Arabic in the classes because we share the same language and I always want Arabic teachers to teach us because it is easier to communicate with them and exchange information. And one more point that foreigner teacher always speak fast and we don't understand them but Arabic teachers speak slowly because they know us and what exactly we need.

This view can be related to his experience as a student, because he states that he was taught by a foreign teacher and did not enjoy the experience.

Student C surprisingly says:

When the teacher uses Arabic in the classes it doesn't mean that his English is bad but he wants the students understand because the main purpose of their teaching is letting the students understand. In Arabic it is easier to convey the message. There some foreigner teachers but honestly we don't understand everything from them. And there is one American teacher who teaches us and she speaks fast, she gets angry easily because most of the students don't participate because we don' understand her.

So students believe that the teachers who teach them are qualified and despite what some research suggests, they do not underestimate the teachers who use L1.

Moreover, Student D considers teachers as role models and says "Honestly, whoever teaches me at this college I consider him/her as a role model, and he/she knows more than me. Teachers know the best ways and strategies to let the students understand more".

Student E adds "The teachers use Arabic because they want the students to understand and we don't see it as a bad thing".

While Student F says "I find it as an advantage talking in Arabic in this case because after her explanation in Arabic we understand".

\section{Discussion}

Based on the data presented in the previous chapter, L2 was the dominant classroom language. This was emphasized by the teacher, who insisted that the students use their L1 based on my observation to her classes. However, this does not mean that the students' L1 is ignored, as the teacher and the students use it to some extent. Although one of the classes was controlled and was supposed not to use L1, the teacher needed to use it for some reasons. L1 was used for many 
purposes, such as grammar explanation, word meaning in L1, jokes telling, sentence translation and classroom management and this had a positive effect on the lesson progression. As noted during the observations, L1 was used 7 times in giving the meaning of some vocabulary, followed by grammar explanation, in which L1 was used for 5 times. In fact, L1 is used most often to explain grammatical rules to students. The teacher and the students also believe that time constrains, students' proficiency level and the type of topic being covered in class, as stated in the previous chapter, are all factors contributing to the use of L1. The reasons are explained in depth in the following section.

\section{Classroom Management}

The teacher has the authority to control the students' behaviour and the use of L1 in this context is related to the teacher's belief that L1 is more effective for disciplinary action than L2. Although the teacher used L1 only once for this purpose, it was very effective to keep the students quieter and clam and if the teacher had used the L2 it will not have the same results.

\section{Word Meaning}

Explaining word meanings in L1 is the most common purpose for the use of L1 by both the teacher and the students. Although the teacher kept repeating the meanings in English, students continued using L1 while facing difficult or abstract words, as they found it easier and more understandable.

\section{Translating sentences into L1}

The teacher used L1 to translate sentences from L2 into L1 to make sure that the students understood what she meant, especially when the students were not responding. As a result, the students reacted positively and enthusiastically and were fully engaged.

\section{Grammar Explanation}

All the lessons I observed were grammar lessons explaining the present perfect tense, which has been classified by the teacher and the students as one of the most difficult grammatical constructions. Grammar teaching was the second most frequent reasons for using L1, after word meaning. Using L1, as believed by the teacher and the students, saves time and helps students to understand grammar more easily than if L2 only is spoken.

\section{Telling Jokes}

Creating a comfortable atmosphere for learning is one of the requirements by the teacher and the learners. Passing comments and telling jokes in L1 helps to reduce stress and tension, and builds a good rapport between learners and the teacher. As was noticed during class observations, the teacher uses jokes in L1 to make sure that the students pay attention, and at the same time adds some humour to the lessons. 


\section{Implications and Conclusion}

As an English language teacher in a country where English is considered a second language, we are encouraged to employ the 'English only' policy in our teaching. Many researchers have shown that a lot of exposure to English can lead to higher proficiency among students. However, there are many reasons why the teachers and students use L1 in the classroom. All the classes are monolingual, in that all students share the same mother tongue, namely Arabic. Due to individual differences and level variation, some teachers use L1 to illustrate some grammar rules as relying on L2 might hinder students' comprehension. This however goes against the official university and school policy. Whether or not to use L1 has been a controversial issue in second language acquisition. Using L1 in the L2 classroom has fruitful effects, as evidenced by the findings, and ignoring this fact is not helpful. It is proven that using L1 facilitates L2 learning and increases students' understanding. Both teachers and learners have positive attitudes toward using L1 and encourage using it, especially while teaching grammar and when facing difficult words which cannot be explained using gestures or the target language. Using L1 also encourages low proficiency students to participate more actively in language lessons and helps them to better understand lesson content. The purposes of using L1 in the L2 classroom are: explaining word meaning, explain grammar rules, managing the classrooms, translating sentence from L2 into L1 and telling jokes. Although using L1 contributes to a better understanding, too much reliance on it could make students too dependent on it, which would go against the main purpose of L2 instruction. Striking a balance between L1 and L2 is one of the best ways to succeed in learning and teaching a second language.

\section{References}

Al Alawi, T. M. (2008). Teachers' beliefs and practices about the use of the L1. In Borg, S. (Ed). Investigating English Language Teaching and Learning in Oman. Muscat: Ministry of Education

Auerbach, E. R. (1993). Reexamining English only in the ESL classroom. TESOL Quarterly, 27(1), pp. 9-32

Blaxter, L., Hughes, C., \& Tight, M. (2010). How to Research. Maidenhead: Open University Press.

Bolitho, A. R. (1976). Translation - An end but not a means. ELT Journal, XXX (2), pp. 110-115.

Borg, M. (2001). Teachers’ beliefs. ELT Journal, 55, pp. 186-188.

Borg, S. (2006). Teacher cognition and Language Education: Research and Practice. London: Continuum.

Chambers, F. (1991). Promoting use of the target language in the classroom. Language Learning Journal, 4, pp. 2731

Chandler, R. (1988). Unproductive busywork. English in Education, 22, pp. 20-28.

Cohen, L. \& Manion, L. (1994). Research Method in Education. London: Routledge.

Dane, F. C. (1990). Research Methods. Pacific Grove, Calif: Brooks/Cole Pub. Co

Davies, P. \& Pearse, E. (2000). Success in English Teaching. Oxford: Oxford University Press.

Driscoll, D. L. (2011). Introduction to primary research: observations, surveys, and interviews. Retrieved from http://www.parlorpress.com/pdf/driscoll--introduction-to-primary-research.pdf (17 August 2015). 
Duff, P. A. \& Polio, C. G. (1990). How much foreign language is there in the foreign language classroom? The Modern Language Journal. 74(2), pp. 154-166

Eisentein-Ebsworth, M. \& Schweers, C. W. (1997). What researchers say and practitioners do: Perspectives on conscious grammar instruction in the ESL classroom. Applied Language Learning, 8, pp. 237-60

Ellis, R. (1984). Classroom Second Language Development. Oxford: Pergamon.

Elo, S. \&Kyngas, H. (2008). The qualitative content analysis process. Journal of Advanced Nursing 62(1), pp. 107115

Hayes, D. (2009). Non-native English-speaking teachers, context and English Language teaching. System, pp. 37 , 1-11.

Krippendorff, K. (2004). Content Analysis: an introduction to its methodology. London: SAGE Publications.

Rivers, D. J. \& McMillan, B. A. (2011). The practice of policy: Teacher attitudes toward “English only”. System, 39, pp. 251-263

Schulz, R. A. (1996). Focus on form in the foreign language classroom: Students' and teachers' views on error correction and the role of grammar. Foreign Language Annals, 29, pp. 343-64.

Schulz, R. A. (2001). Cultural differences in student and teacher perceptions concerning the role of grammar teaching and corrective feedback: USA-Colombia. Modern Language Journal, 85, pp. 244-58.

Tuckman, B. W. (1972). Conducting Educational Research. New York: Harcourt Brace Jovanovich.

Wilkinson, D. \& Birmingham, P. (2003). Using Research Instruments: A guide for researcher. London: Routledge Falmer.

Woods, D. (1996). Teacher Cognition in Language Teaching: Beliefs, decision-making and classroom practice. Cambridge: Cambridge University Press. 